DOI: 10.20472/IAC.2019.051.041

EK-ANONG TANGRUKWARASKUL

Kasetsart University, Thailand

KIRIYA KULCHANARAT

Kasetsart University, Thailand

\title{
COMPARATIVE ANALYSIS OF FINANCIAL PERFORMANCE OF HEALTHCARE FIRMS IN THE STOCK EXCHANGE OF THAILAND USING TOPSIS TECHNIQUE
}

\begin{abstract}
:
Regarding Megatrends, healthcare is one of the most popular sector for investors. Global healthcare expenditures are expected to continue to rise as spending is projected to increase at the rate of 5.4 percent per annum, from USD \$7.724 trillion in 2017 to USD \$10.059 trillion in 2022. Results from CBRE's recent EMEA-wide Investor Survey show that healthcare is one of the most popular subsectors of the alternatives market and that large numbers of investors are looking to get into the sector. Firm's financial performance is often used as the key metrics when making investment decision. However, a number of financial ratios has to be collectively considered in order to provide an appropriate evaluation of financial performance. This study aims to propose a multi-criteria decision-making (MCDC) model to measure and compare the financial performance of twenty-three healthcare firms listed in Thailand Stock Exchange. These firms are examined and assessed in terms of eight financial ratios which are combined to obtain a financial performance score by using Technique for Order Preference by Similarity to Ideal Solution Methods (TOPSIS). TOPSIS helps to rank these firms for three-year time period between 2016 and 2018. This study will find out whether the ranking results of TOPSIS and whether the firms can keeps their position throughout the three years.
\end{abstract}

\section{Keywords:}

Multi-Criteria Decision Making (MCDC), TOPSIS, Healthcare Sector, Financial Performance

JEL Classification: D70, G10 